\section{Increasing Honey Bee Hive Densities Promotes Pollination and Yield Components of Highbush Blueberry in Western Washington}

\author{
Matthew Arrington ${ }^{1,3}$ and Lisa Wasko DeVetter ${ }^{2,3}$ \\ Department of Horticulture, Washington State University, Northwestern \\ Washington Research and Extension Center, 16650 State Route 536, Mount \\ Vernon, WA 98273
}

Additional index words. Vaccinium corymbosum, pollination, fruit set, Apis mellifera, pollination efficiency

\begin{abstract}
Yield components including fruit set and berry size in northern highbush blueberry (Vaccinium corymbosum) can be limited in key production regions like western Washington. Climactic conditions influence the activity levels of blueberry's primary commercial pollinator, honey bee (Apis mellifera). Cool springs with frequent rainfall, which are common during the spring bloom period in western Washington, can reduce honey bee activity, pollination efficiency, and subsequent fruit set and yields. Increasing honey bee hive density may be a simple technique that growers can employ to increase the number of honey bees foraging during periods of good weather, interspersed with the poor weather, and therefore, increase fruit set and related yield components. The objective of this study was to evaluate if increased honey bee hive densities improve pollination and subsequent yield components in western Washington blueberry. Three field sites with mature 'Duke' plants were stocked with 10 hives/ha of honey bees (control), and three other field sites (also 'Duke') were stocked with 20 hives/ha (high hive density). Honey bee visitation and yield components, including fruit set and berry weight, were measured. Estimated yield, seed number/berry, and fruit firmness were also monitored. There were no significant differences in fruit set regardless of honey bee hive density. However, honey bee visitation and estimated yield increased with increased honey bee hive density. Berry weight and seed number per berry were also increased with increased honey bee hive density, although firmness was unaffected. Results indicate that increasing honey bee hive densities can help blueberry growers improve berry size and overall yields, suggesting this is a practice growers can implement if their production is constrained by insufficient pollination.
\end{abstract}

Washington State leads in the production of highbush blueberry ( $V$. corymbosum) in the United States, with 54 million kg produced from 5423 ha in 2016 [United States Department of Agriculture National Agricultural Statistics Service (USDA NASS, 2017)]. One of the most challenging production issues for blueberry cultivation in western Washington is pollination and subsequent fruit set and reduced yields.

Effective insect-mediated pollination is important for optimal fruit set and maximizing berry size in highbush blueberry (MacKenzie, 1997). Most commercial producers in Washington and the greater Pacific Northwest (PNW) rent hives of Italian honey bees (A. mellifera ligustica) for pollination

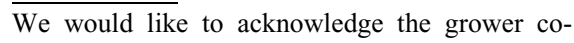
operators who participated in this trial, Bellevue Bees for their assistance with treatment application, and the Washington Blueberry Commission for funding.

${ }^{1}$ Graduate Research Assistant.

${ }^{2}$ Assistant Professor.

${ }^{3}$ Corresponding authors. E-mail: matthew.arrington@ wsu.edu or lisa.devetter@wsu.edu.
}

by honey bees because of its oceanic climate and northerly latitude $\left(\approx 47^{\circ} \mathrm{N}\right)$. Rainfall and cloud cover is probable between October and May with as many as six out of seven cloudy days per week, further restricting solar radiation and the ability of honey bees to offset cooler temperatures with light (Western Regional Climate Center, 2017). Honey bees exhibit reduced foraging when air temperature is below $\approx 12{ }^{\circ} \mathrm{C}$ and when wind speeds are above $19 \mathrm{~km} \cdot \mathrm{h}^{-1}$ (Delaplane et al., 2000). The close proximity of western Washington to the Puget Sound increases the likelihood of coastal breezes exceeding this threshold. Consequently, reduced honey bee foraging during key pollination periods may negatively impact fruit set and other yield components in blueberry cultivated in western Washington and elsewhere in the PNW.

In addition to the reduced foraging activity during inclement spring weather, honey bees also have a shorter average tongue length than bumble bees (Bombus spp.), a pollinator that is highly adapted to pollinate blueberry (Balfour et al., 2013). This makes access to nectar rewards more difficult for honey bees foraging on blueberry. Honey bees also lack the ability to sonicate, or "buzz pollinate," which is the vibration of flight muscles causing dehiscence of pollen from poricidal anthers. The inability to sonicate makes collection of blueberry pollen by honey bees more difficult relative to pollinators like bumble bees, which are able to sonicate.

Berry weight/size in highbush blueberry is positively related to seed number, so maximizing ovule fertilization and seed production is important in achieving large berry size (Pritts and Hancock, 1992). Larger fruit generally have a greater number of cells; however, marketable size has reportedly been achieved with as few as 10-20 seeds/fruit in some cultivars of northern highbush blueberry (Coombe, 1976; Vorsa, 1996). Given the low honey bee visitation rates observed in a recent statewide survey in western Washington, which was below the recommended 4-8 honey bees/bush guideline, fruit set and yield enhancement through promotion of berry size may start with increasing pollination in the field (DeVetter et al., 2016; Isaacs et al., 2016).

Honey bees used for commercial pollination of blueberry in western Washington and elsewhere in the PNW are frequently stocked at a density of 10 hives/ha; however, there is some variation because of the cultivar (DeVetter et al., 2016; Sagili and Burgett, 2011). These stocking density recommendations rely on healthy hives and proper timing of hive placement for optimal pollination efficiency. This project evaluates the current recommended hive stocking density for honey bees in the PNW region compared with a higher hive stocking density in 'Duke' blueberries. An evaluation of honey bee hive stocking density is justified in northwestern Washington because increased honey bee foraging may promote pollination and 
subsequent yield components during the compressed bloom window and during spring conditions where weather is unconducive to honey bee activity.

\section{Materials and Methods}

Data were collected from six commercial field sites in western Washington in 2016 and 2017. All six sites were mature 'Duke' plantings $(\approx 5$ years or older) and were geographically separated by $>2 \mathrm{~km}$ to maintain site independence and reduce the likelihood that observed honey bees were from other hives. At each site, three rows separated by a buffer row were flagged. Within each row, 10 bushes spaced $10 \mathrm{~m}$ apart were selected, flagged, and revisited throughout the study for the collection of pollination and yield component data (30 bushes/site). Honey bee hives were sourced from a commercial beekeeper (Belleville Bees, Burlington, WA) and stocked at 10 or 20 hives/ha at our experimental sites. All sites were stocked with bees from the same beekeeper, and grower/bee keeper rental contracts specified the same colony size (10 frames/hive box; $\approx 30,000$ bees/colony). Three field sites were assigned the 10 hive/ha treatment, whereas the remaining three sites were assigned the 20 hive/ha treatment. Care was taken to coordinate with cooperating growers and the beekeeper to ensure that spacing and hive placement were consistent across the study ( $\approx 16$ hives/drop with $100 \mathrm{~m}$ between drops). Hive boxes were placed in areas designated by the grower with no more hive boxes than the predetermined hive/ha amount within the hectare diameter with the sampled bushes at the epicenter. Hives were placed between $10 \%$ and $20 \%$ full bloom and remained in the field through petal fall.

Honey bee visitation rates and colony strength were determined between $20 \%$ and $100 \%$ bloom. These measurements were recorded after 10:00 $\mathrm{Am}$ and before 4:00 PM, at air temperatures above $18{ }^{\circ} \mathrm{C}$, when wind speeds were below $16 \mathrm{~km} \cdot \mathrm{h}^{-1}$, and during periods without precipitation. Honey bee visitation was determined by enumerating the number of legitimate flower visits by honey bees within a 1-min period/bush and was repeated three times per day. Legitimate visits included the insertion of the honey bee head within the corolla; nectar robbing and failed pollination attempts were not recorded. Honey bee visitation was determined for each site on three separate days during the bloom period and totaled 270 measurements/site $(90$ measurements site/day $\times 3 \mathrm{~d}=270$ measurements/site). The colony strength was determined before and after collecting honey bee visitation data by counting the number of honey bees returning to a randomly selected hive box within five 1-min intervals. Sagili and Burgett (2011) indicate that honey bee hives in good health have $\approx 100$ or more bees returning to the hive per minute when air temperatures are at or above $18{ }^{\circ} \mathrm{C}$ and wind speeds are below $16 \mathrm{~km} \cdot \mathrm{h}^{-1}$. In addition to honey bee visitation, pollinator visitation by
non-Apis bees was also recorded during the same periods of observation.

All flagged plants/site were evaluated for select yield components including fruit set and average berry weight. Fruit set was determined by first counting the number of flowers within four flower clusters/bush (third cluster from the shoot apex). Fruit set was then recorded when developing fruits were $\approx 4 \mathrm{~mm}$ in diameter. At $\approx 75 \%$ blue and before commercial harvest, fruit samples (10 berries/bush $\times 30$ bushes $/$ site $=300$ berries/ site) were collected to determine the average berry weight. Estimated yield was also determined by counting the number of canes/ bush, determining the average number of fruiting clusters/cane from two randomly selected canes/bush, and determining the average number of developing berries/cluster from four clusters/cane (third cluster from the shoot apex)/bush. Estimated yield was subsequently calculated by first determining the average berry number/bush using the following equation:

$$
\begin{aligned}
& \text { Berry number/bush } \\
& \begin{aligned}
= & (\text { cane number } / \text { bush }) \\
& \times(\text { average number of fruit clusters } / \text { cane }) \\
& \times(\text { average berry number/cluster })
\end{aligned}
\end{aligned}
$$

Berry number/bush was then multiplied by the average berry weight/bush to determine estimated yield/bush, which was then averaged across the site.

A subsample (60 berries/row) of harvested berries was measured for firmness (FirmTech II machine; BioWorks Inc., Wamego, KS). The FirmTech was set up with maximum and minimum compression forces of $200 \mathrm{~g}(1.96 \mathrm{~N})$ and $15 \mathrm{~g}(0.15 \mathrm{~N})$, respectively. Piston speed was configured to $6 \mathrm{~mm} \cdot \mathrm{s}^{-1}$ (Ehlenfeldt and Martin, 2002; Saftner et al., 2008). Seed number/berry was determined by crushing berries $(n=$ $20 /$ row) in $1 \mathrm{~L}$ of water and filtering seeds through a 2-mm screen (B. Strik, unpublished data). This method allowed skin and pulp fragments to float and enabled these fragments to be poured off. Seeds were rinsed, resuspended in $1 \mathrm{~L}$ of water, and floating fragments were poured off twice more. The seeds were then filtered through a coffee filter and allowed to dry for 7-10 d. Seeds were then counted for average seed number/berry.

Air temperature, precipitation, wind speed, and solar radiation were measured at 15-min intervals throughout the bloom periods (1 Mar. through 31 May) by Washington State University AgWeatherNet (WSU AgWeatherNet, 2017; data provided courtesy of WSU AgWeatherNet and are copyright of WSU). Weather station sites were no more than $3.2 \mathrm{~km}$ from the experiment locations.

Data analysis. Data were evaluated for normality and equal variance before analysis of variance. Data were first analyzed by site and year; means were combined when no significant interactions were found. Mean separations were performed with Tukey's honest significant difference test. The relationship of individual explanatory variables to yield components was tested by analyzing the coefficient of determination $\left(R^{2}\right)$. Individual variables were considered significant at $\alpha \leq 0.05$. The cov.test function was used to evaluate the relationship between seed number and berry weight. All statistical analyses were carried out in R-studio Version 2.15.3 statistical platform (R Development Core Team; R Foundation for Statistical Computing, Vienna, Austria) using the "cran", "agricolae", "Ime4", and "ggplot" statistical packages (Mendiburu, 2014; RStudio Team, 2015; Wickham, 2009).

\section{Results}

When honey bee hive density was increased to 20 hives/ha, honey bee visitation, estimated yield, and berry characteristics (weight and seed number) were increased. Bloom number/bush was the same across sites, indicating that the sites were comparable with regard to bloom characteristics (data not shown). There were significant differences between 2016 and 2017 for honey bee visitation, fruit set, estimated yield, seed number/berry, and berry weight; berry firmness was unaffected by year and was the same across the treatments (Table 1; Figs. 1 and 2). Bees returning to a hive/minute was used as a measure of colony foraging strength. No significant differences in foraging strength were observed between treatments (average returning bees $/$ minute $=117, P$ value $=$ 0.7114; data not shown). Observed average weather conditions were comparable between 2016 and 2017 (Table 2).

Although an increase in the number of honey bee visits in the 20 hives/ha treatment compared with the control of 10 hives/ha was observed (Fig. 1), fruit set was not found to increase concurrently (Table 1). No signifi-

\begin{tabular}{|c|c|c|c|c|c|c|c|}
\hline \multirow[b]{2}{*}{ Treatment } & \multicolumn{2}{|c|}{ Fruit set $(\%)$} & \multicolumn{2}{|c|}{ Berry wt (g/berry) } & \multicolumn{2}{|c|}{ Seed no./berry } & \multirow{2}{*}{$\begin{array}{c}\begin{array}{c}\text { Firmness }\left(\mathrm{g} \cdot \mathrm{mm}^{-1} \text { of }\right. \\
\text { deflection })\end{array} \\
2016-17\end{array}$} \\
\hline & 2016 & 2017 & 2016 & 2017 & 2016 & 2017 & \\
\hline 10 hives/ha & 93.9 & 96.2 & $1.4 \mathrm{~b}^{\mathrm{z}}$ & $1.6 \mathrm{~b}$ & $16.8 \mathrm{~b}$ & $15.5 \mathrm{~b}$ & 326.4 \\
\hline 20 hives/ha & 95.2 & 99.0 & $1.8 \mathrm{a}$ & $2.0 \mathrm{a}$ & $21.2 \mathrm{a}$ & $22.7 \mathrm{a}$ & 352.8 \\
\hline$P$ value & 0.2512 & 0.4131 & $<0.001$ & $<0.001$ & $<0.001$ & $<0.001$ & 0.4772 \\
\hline
\end{tabular}
cant differences between sites in the

Table 1. Fruit set, berry weight, seed number/berry, and berry firmness of 'Duke' blueberry stocked with honey bee hives at 10 or 20 hives/ha in 2016 and 2017.

${ }^{\mathrm{z}}$ Mean separations were performed with Tukey's honest significant difference test; means with the same letter are not different at $P \leq 0.05$; means were combined across both years when analyses revealed no significant interaction because of year. 
visitation rates of non-Apis bees were observed (data not shown). The high hive density treatment did increase the average berry weight (16\% in 2016 and $27 \%$ in 2017 ; $P$ value $\leq 0.001$ and $<0.001$, respectively) and seed number/berry (20\% in 2016 and $31 \%$ in $2017 ; P$ value $\leq 0.001$ and $<0.001$, respectively) relative to the control (Table 1). Estimated yield also increased for sites treated with 20 hives/ha and were $22 \%$ and $40 \%$ greater than the control stocking rate in 2016 and 2017, respectively (Fig. 2; $P$ value $=$ 0.0481 and $<0.001$ for 2016 and 2017, respectively).

Honey bee visits/bush/minute were positively correlated with seed number/berry $\left(R^{2}=\right.$ 0.61 and $P$ value $\leq 0.001$ ). Honey bee visits/ bush/minute was also positively correlated with berry weight $\left(R^{2}=0.47\right.$ and $P$ value $\leq 0.001)$. Additionally, the number of seeds/ berry was positively correlated with berry weight $\left(R^{2}=0.50\right.$ and $P$ value $\left.\leq 0.001\right)$ (Fig. 3).

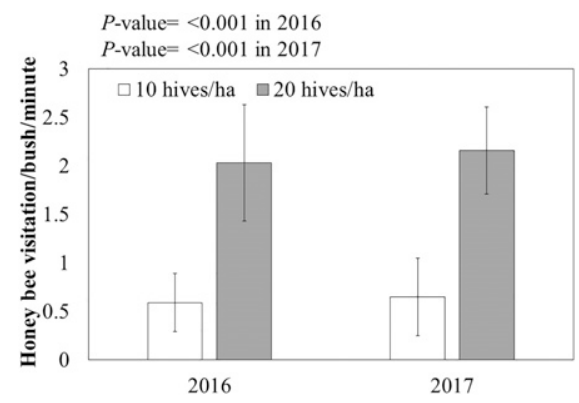

Fig. 1. Honey bee visitation/bush/minute in blueberry sites stocked with 10 or 20 hives/ha in 2016 and 2017. Error bars represent standard error.

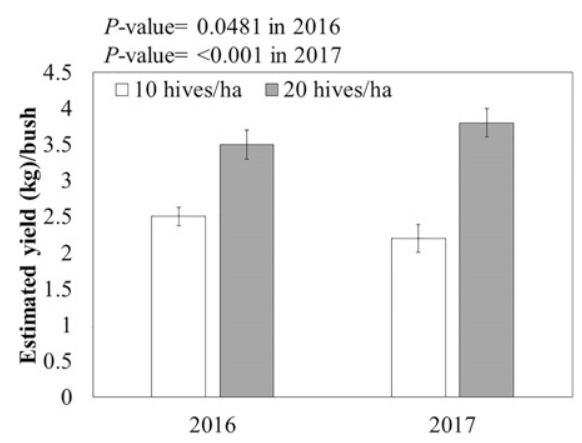

Fig. 2. Estimated yield/bush of blueberry sites stocked with 10 or 20 hive/ha in 2016 and 2017. Error bars represent standard error.

Table 2. Environmental conditions during the 2016 and 2017 pollination period for western Washington Weather data were collected every $15 \mathrm{~min}$; data are provided courtesy of WSU AgWeatherNet and are copyright of WSU.

\begin{tabular}{|c|c|c|c|c|}
\hline $\mathrm{Yr}$ & Air temp $\left({ }^{\circ} \mathrm{C}\right)$ & Total precipitation $(\mathrm{mm})$ & Solar radiation $\left(\mathrm{W} \cdot \mathrm{m}^{-2}\right)$ & Wind speed $\left(\mathrm{km} \cdot \mathrm{h}^{-1}\right)$ \\
\hline 2016 & $14.7^{\mathrm{z}}$ & 11 & 344.3 & 16 \\
\hline 2017 & 14.3 & 14 & 472.2 & 14 \\
\hline
\end{tabular}

HortScience Vol. 53(2) February 2018 been noted to influence the response of fruit size to increased seed number (Eaton, 1967); therefore, care should be taken in comparing these relationships between cultivars and types of blueberry.

Despite the observed treatment effects in sites with increased honey bee stocking densities, the number of honey bees/bush/minute remained below the recommended $4-8$ honey bees/bush recommendation (Isaacs et al., 2016). This suggests that there may be additional benefits of increasing honey bee stocking densities at even greater levels than what was experimented with in this project. The primary drawback of increasing honey bee stocking densities is cost incurred by the grower, particularly at or past the point of diminishing returns. We performed a preliminary benefit-cost analysis using price information provided by our grower cooperators and data from this project. We determined that the increased hive stocking density resulted in a net increase in revenue of $\approx \$ 830 /$ ha. This net increase was realized at the rental price of $\$ 80 /$ hive. A more comprehensive benefit-cost analysis would be beneficial to establish the economic viability of increasing honey bee hive densities.

Although this study only evaluated the foraging of Italian honey bees at different stocking densities, Carniolan (A. mellifera carnica) or Caucasian (A. mellifera caucasica) honey bees may forage under more broad weather conditions. The use of these subspecies of honey bees may further promote pollination of blueberries grown in climates with unfavorable spring climactic conditions during the bloom and pollination period. Furthermore, the contributions of non-Apis bees like bumble bees (Bombus sp.) or orchard bees (Osmia sp.) are not fully known in this growing region. Although we did not observe significant differences in non-Apis pollinators between sites, it is possible that more broad observation timings or more frequent sampling could have provided a better representation, given the smaller populations of these insects relative to commercially supplied honey bees.

Despite the increase in estimated yield, fruit set was not found to differ by treatment. The increase in estimated yield is likely attributed to the increase in berry weight observed with the high hive density treatment. In addition, fruit set for sites treated with the control (10 hives/ha) stocking density was above $90 \%$ in both 2016 and 2017 , which may have made it more difficult to perceive a treatment effect for fruit set. The relatively high fruit set in 2016 and 2017 may have been due to the near optimal conditions for pollination during the 'Duke' bloom window. In addition, 'Duke' has a relatively large flower size compared with other commercially used cultivars in western Washington and the PNW, particularly 'Bluecrop', 'Draper', and 'Liberty' (Courcelles et al., 2013). This larger flower size observed in 'Duke' likely increases the accessibility of pollen and nectar to honey bees and the overall effectiveness of pollination by honey 


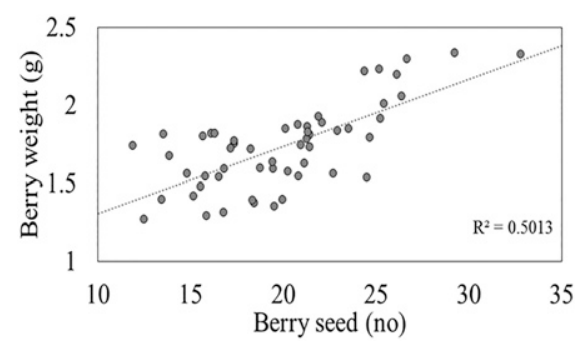

Fig. 3. Relationship between seed number/berry and berry weight fitted with a general linear model.

bees (Courcelles et al., 2013). Although pollination issues in 'Duke' may not be as problematic as other cultivars planted in western Washington and the PNW (e.g., 'Draper' and 'Liberty'), 'Duke' is the most widely planted cultivar and is an industry standard. These results are likely still applicable to other cultivars, and this study suggests that increasing the stocking densities of Italian honey bee will promote yield among other cultivars of highbush blueberry.

\section{Literature Cited}

Alonso, C., J.C. Vamosi, T.M. Knight, J.A. Steets, and T.L. Ashman. 2010. Is reproduction of endemic plant species particularly pollen limited in biodiversity hotspots? Oikos 119 (7):1192-1200.

Balfour, N.J., M. Garbuzov, and F.L. Ratnieks. 2013. Longer tongues and swifter handling: Why do more bumble bees (Bombus spp.) than honey bees (Apis mellifera) forage on lavender (Lavandula spp.)? Ecol. Entomol. 38(4):323329.

Benjamin, F.E. and R. Winfree. 2014. Lack of pollinators limits fruit production in commercial blueberry (Vaccinium corymbosum). Environ. Entomol. 43(6):1574-1583.

Brewer, J.W. and R.C. Dobson. 1969. Seed count and berry size in relation to pollinator level and harvest date for the highbush blueberry, Vaccinium corymbosum. J. Econ. Entomol. 62 (6): 1353-1356.

Buchmann, S.L. 1985. Bees use vibration to aid pollen collection from non-poricidal flowers. J. Kans. Entomol. Soc. 37(2):517-525.

Coombe, B.G. 1976. The development of fleshy fruits. Annu. Rev. Plant Physiol. 27(1):207228.

Courcelles, D.M., L. Button, and E. Elle. 2013. Bee visit rates vary with floral morphology among highbush blueberry cultivars (Vaccinium corymbosum L.). J. Appl. Entomol. 137(9):693-701.
Danka, R.G., G.A. Lang, and C.L. Gupton. 1993. Honey bee (Hymenoptera: Apidae) visits and pollen source effects on fruiting of 'Gulfcoast' southern highbush blueberry. J. Econ. Entomol. 86(1):131-136.

Delaplane, K.S., D.R. Mayer, and D.F. Mayer. 2000. Crop pollination by bees. CABI, CAB International, Wallingford, UK.

DeVetter, L.W., S. Watkinson, R. Sagili, and T. Lawrence. 2016. Honey bee activity in northern highbush blueberry differs across growing regions in Washington State. HortScience 51:1228-1232.

Dogterom, M.H., M.L. Winston, and A. Mukai. 2000. Effect of pollen load size and source (self, outcross) on seed and fruit production in highbush blueberry cv. 'Bluecrop' (Vaccinium corymbosum; Ericaceae). Amer. J. Bot. 87 (11):1584-1591.

Eaton, G.W. 1967. The relationship between seed number and berry weight in open-pollinated highbush blueberries. HortScience 2:14-15.

Ehlenfeldt, M.K. and R.B. Martin. 2002. A survey of fruit firmness in highbush blueberry and species-introgressed blueberry cultivars. HortScience 37:386-389.

Ehlenfeldt, M.K. and R.B. Martin, Jr. 2009. Seed set, fruit weight, and yield in highbush ( $\mathrm{Vacci}$ nium corymbosum 1.) Blueberry cultivars 'Duke' and 'Bluecrop'. J. Amer. Pomol. Soc. 64(3):162-172.

Garibaldi, L.A., I. Steffan-Dewenter, R. Winfree, M.A. Aizen, R. Bommarco, S.A. Cunningham, C. Kremen, L.G. Carvalheiro, L.D. Harder, O. Afik, and I. Bartomeus. 2013. Wild pollinators enhance fruit set of crops regardless of honey bee abundance. Science 339(6127):1608-1611.

Howell, G.S., M.W. Kilby, and J.W. Nelson. 1972. Influence of timing of hive introduction on production of highbush blueberries. HortScience 7:129-131.

Isaacs, R., J. Gibbs, and E. May. 2016. Invest in pollination for success with highbush blueberries. MSU Extension. 6 Oct. 2017. <http:// msue.anr.msu.edu/news/invest_in_pollination_ for_success_with_highbush_blueberries $>$.

Javorek, S.K., K.E. Mackenzie, and S.P. Vander Kloet. 2002. Comparative pollination effectiveness among bees (Hymenoptera: Apoidea) on lowbush blueberry (Ericaceae: Vaccinium angustifolium). Ann. Entomol. Soc. Amer. 95 (3):345-351.

Johnson, L. K., A. Malladi, and D.S. NeSmith. 2011. Differences in cell number facilitate fruit size variation in rabbiteye blueberry genotypes. J. Amer. Soc. Hort. Sci. 136:10-15.

Knight, T.M., J.A. Steets, J.C. Vamosi, S.J. Mazer, M. Burd, D.R. Campbell, M.R. Dudash, M.O. Johnston, R.J. Mitchell, and T.L. Ashman. 2005. Pollen limitation of plant reproduction: Pattern and process. Annu. Rev. Ecol. Evol. Syst. 36(1):467-497.
Krebs, S.L. and J.F. Hancock. 1988. The consequences of inbreeding on fertility in Vaccinium corymbosum L. J. Amer. Soc. Hort. Sci. 113:914-918.

Lee, T.D. 1988. Patterns of fruit and seed production, p. 179-202. In: J. Lovett Doust and L. Lovett Doust (eds.). Plant reproductive ecology: Patterns and strategies. Oxford University Press, New York, NY.

MacKenzie, K.E. 1997. Pollination requirements of three highbush blueberry (Vaccinium corymbosum L.) cultivars. J. Amer. Soc. Hort. Sci. 122:891-896.

Mendiburu, F. 2014. Statistical procedures for agricultural research; package 'agricolae'. Natl. Eng. Univ., Lima Peru, MS Diss.

Pritts, M.P. and J.F. Hancock. 1992. Highbush blueberry production guide. Northeast Region Agricultural Engineering Service NRAES-55.

Retamales, J.B. and J.F. Hancock. 2012. Blueberries, Vol. 21. CABI, CAB International, Wallingford, UK.

RStudio Team. 2015. RStudio: Integrated Development for R. RStudio, Inc., Boston, MA. 15 Nov. 2017. <http://www.rstudio.com>.

Saftner, R., J. Polashock, M. Ehlenfeldt, and B. Vinyard. 2008. Instrumental and sensory quality characteristics of blueberry fruit from twelve cultivars. Postharvest Biol. Technol. 49(1):19-26.

Sagili, R.R. and D.M. Burgett. 2011. Evaluating honey bee colonies for pollination: A guide for commercial growers and beekeepers. Pacific Northwest Extension publication PNW 623.

Tuell, J.K., J.S. Ascher, and R. Isaacs. 2009. Wild bees (Hymenoptera: Apoidea: Anthophila) of the Michigan highbush blueberry agroecosystem. Ann. Entomol. Soc. Amer. 102(2):275287.

Tuell, J.K. and R. Isaacs. 2010. Weather during bloom affects pollination and yield of highbush blueberry. J. Econ. Entomol. 103(3):557-562.

United States Department of Agriculture National Agricultural Statistics Services (USDA NASS). 2017. Noncitrus fruits and nuts 2016 summary. 15 Sept. 2017. <https://www.nass. usda.gov/>.

Vorsa, N. 1996. On a wing: The genetics and taxonomy of Vaccinium species from a pollination perspective. Acta Hort. 446(7):59-66.

Washington State University (WSU) AgWeatherNet. 2017. AgWeatherNet. 16 Nov. 2017. $<$ http://weather.wsu.edu/>.

Western Regional Climate Center. 2017. Average number of cloudy days. 21 Oct. 2017. <https:// wrcc.dri.edu/htmlfiles/westcomp.ovc.html $>$.

White, E. and J.H. Clarke. 1939. Some results of self-pollination of the highbush blueberry at Whitesbog, NJ. Proc. Amer. Soc. Hort. Sci. 36:305-309.

Wickham, H. 2009. 'ggplot2': Elegant graphics for data analysis. Springer, New York, NY. 